\title{
RESEARCH PROCESSES AND METHODOLOGICAL TRIANGULATION
}

\author{
Henryk DŹWIGOŁ ${ }^{1 *}$, Mariola DŹWIGOŁ-BAROSZ ${ }^{2}$ \\ ${ }^{1}$ Silesian University of Technology, Faculty of Organisation and Management, Zabrze; \\ henryk.dzwigol@poczta.fm, ORCID: 0000-0002-2005-0078 \\ ${ }^{2}$ Silesian University of Technology, Faculty of Organisation and Management, Zabrze; \\ mariola.dzwigol-barosz@polsl.pl, ORCID: 0000-0002-5306-3836 \\ * Correspondence author
}

Purpose: The aim of the article was to verify whether methodological triangulation supports research processes in management science.

Design/methodology/approach: In order to verify the hypothesis, quantitative research (survey questionnaire) and qualitative research (interview questionnaire) were conducted. Quantitative research was addressed to a group of management science theoreticians being a target group. As a result of the research effort undertaken, 401 representatives of management science theoreticians were examined.

Findings: The statistical conclusions of the research conducted among management scientists clearly show that a significant proportion (66\%) believes that methodological triangulation is a necessary condition in the research process. Moreover, as many as $82 \%$ of the above mentioned respondents claim that triangulation supports the research process.

Originality/value: It is necessary to use a variety of testing methods that provide a comprehensive response to the posed research problem.

Keywords: Research process, methods, research techniques, methodological triangulation.

\section{Introduction}

The $21^{\text {st }}$ century, characterised by a high level of variability, functioning in a tumultuous environment or adapting to the ever-increasing demands of the environment, shapes new concepts and trends in management. Enterprises wishing to succeed are compelled to seek new solutions, methods, tools or techniques to support their compliance with market requirements.

Research methods and techniques have undergone profound changes and development in recent years (Ferran-Ferrer et al., 2017; Almalki, 2016; Tonidandel et al., 2016). In management science there occur changes associated with the transition from traditional thinking to combined thinking (Hair, 2019; Dźwigoł, 2019). Research methods and techniques in management 
science are primarily aimed at discovering rules and principles governing organisations and improving them (Quinlan et al., 2019).

Management science is assigned with a set of methods and techniques through which empirical data are obtained (Bryman, 2006; Vaivio et al., 2010). In classical terms, one can distinguish methods such as: observational, experimental, documentary research and other methods and corresponding techniques, among which are: observation, interview, document research, etc. (Walliman, 2017). However, with the development of this discipline, the applied research techniques have also changed (Almalki, 2016). Nowadays, it is more and more important to apply new solutions that increase research effectiveness, manifesting itself in the improved quality of obtained research results, reduced costs of conducting it and its shortened duration. Currently, greater emphasis is placed on the use of such techniques, in which IT support tools are applied (Tonidandel et al., 2016).

In the social science, three groups of research methodologies have been adopted, i.e.: quantitative research, qualitative research, mixed methods (methodological triangulation). Quantitative research methods are methods aimed at making specific measurements, measuring specific phenomena (Apuke, 2017). This research in itself does not always enable the development of new knowledge. Therefore, scientific research should not be based solely on quantitative research methods. Quantitative research should be carried out if the researcher has a feeling that he or she has good understanding of the nature of the phenomenon and the factors that govern it (Park, and Park, 2016). It can therefore be concluded that quantitative research methods should be used by the researcher to measure the extent of occurrence of phenomena, and in which the researcher has a deep insight. Inferencing, which is based on the results of quantitative research, is subject to the rules of mathematical statistics and allows to translate the results from the research sample into the general population.

In recent years, the popularity of qualitative research methods, which are increasingly used in social sciences, has been growing (Boddy, 2016; Hammarberg et al., 2016). This trend can also be seen in the sciences on organisation and management. The reasons for that can be found in increasing organisational trends, such as paying more attention to social aspects of management (Dźwigoł et al., 2019). Qualitative methods of research - due to their specific nature - affect the actions taken by people, which makes it possible to analyse newly emerging phenomena, define new categories and concepts. They also allow to put forward theses, which are the basis for the application of quantitative methods (Boddy, 2016).

Blended research methods combine both quantitative and qualitative elements in scientific inquiries. The characteristics of qualitative and quantitative methods are listed below:

- qualitative - soft, flexible, subjective, political, speculative, case studies,

- quantitative - hard, structured, objective, non-evaluative, surveys, hypothesis-testing, abstract (Dźwigoł, 2018). 
It is assumed that qualitative research does not have to be conducted according to rigid rules, is more subjective in nature, and is somehow 'marked' by the presence of the researcher, who can influence the respondents through appropriately asked questions. However, the results cannot be adjusted to the entire population.

Quantitative research, in turn, is looking for the answer to the question 'how much?'. It goes in accordance with a predetermined framework. The results are numerical values that can be applied to the whole population, and their interpretation is not marked by the subjective approach of the researcher.

The above indications directly force the current research processes to combine qualitative and quantitative methods (Joslin, and Müller, 2016). This is due to the growth of the entity, the research subject and the quality of the research process, which is conditioned by the continuity of changes triggered by the market, especially in management science. Increasingly, attention is being paid to the use of a package of diverse methods (Dźwigoł et al., 2019) so that to achieve consistency of bases within empirical inference (Kostera, 2003), i.e. research triangulation. Triangulation, as the authors claim (Jick, 1979) is not a method, but rather a research strategy, methodological process, research procedure or proceeding (Stańczyk, 2016). In research practice, triangulation will be a method of conduct that aims at such a selection of complementary methods that will allow to obtain convergent results. It should be pointed out that convergent results do not mean consistent or identical research results the results obtained may not be identical, but should allow for a deeper understanding of the relationship between the researcher's approach and the analysed phenomenon.

Many authors overlook ontological and epistemological issues and their links with methodology, focusing excessively on empirical problems. Although methods can be combined, one must not go beyond the same theoretical scope (ontological and epistemological) (Heesen et al., 2019). One cannot be both positivist when using quantitative methods, and interpretative while employing qualitative methods.

Thus, the positivists will rather ask questions that lead to general truths and receive answers using quantitative methods, while in the framework of 'data triangulation' they are only supported by qualitative methods. Different researchers will interpret their results differently: the positivist will consider the results to be 'true' and the relativist will consider that he/she discovered one of the possible interpretations (Heesen et al., 2019; Joslin, and Müller, 2016).

\section{Research method}

Findings from domestic and foreign literature analyses on methodological triangulation indicate a necessity to carry out an in-depth analysis of how research methods are combined within the research process, with a consideration given to a broad context of management 
science. Thus, the research problem was formulated as follows: Is methodological triangulation a prerequisite for research processes in the management sciences?

Therefore, the following research questions were posed in the article:

Q1 Is methodological triangulation a necessary condition in research processes?

Q2 Does the researcher influence the combination of quantitative and qualitative methods in the research process?

Q3 Once the research problem has been identified, is it necessary to analyse the selected quantitative and qualitative methods for their initial selection?

Q4 Does methodological triangulation support research processes?

Q5 Does the combination of qualitative and quantitative methods in research processes in management science improve the quality and make the research results reliable?

Providing answers to such research questions will allow to verify the following hypothesis: 'Methodological triangulation supports research processes in management sciences'.

In order to obtain answers to the posed research questions, the research was conducted using an anonymous questionnaire and then a structured interview. The research was conducted in the period from October 2016 to April 2018.

The questionnaire consisted of three parts (Dźwigot, 2018):

1. questions on the relevance of approaches, processes, methods and techniques in the research process in management science (5 questions).

2. questions on the problem of improving the research process (33 questions).

3. demographics (3 questions).

The interview questionnaire, on the other hand, consisted of an introduction in the form of a letter of intent, two questions in an open form and final information containing thank-you note and contact details for sending the answers. Respondents were asked the following questions: 'Does the combination of qualitative and quantitative methods in research processes in management science improve the quality and make the research results reliable?' and 'Which of the qualitative and quantitative methods broaden the new paradigm of management in relations between science and business practice?'.

The quantitative research (questionnaire) was addressed to the theoreticians of management science as a target group. As a result of the research effort undertaken, 401 theoreticians of management science were examined. 


\section{Research findings}

\subsection{Is methodological triangulation a prerequisite for research processes?}

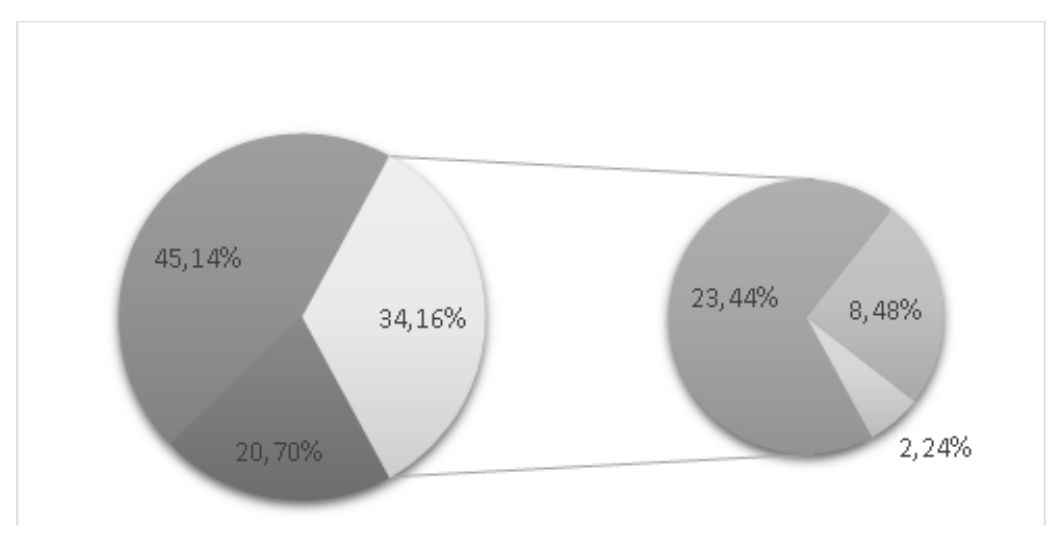

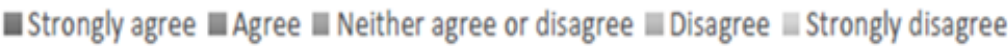

Figure 1. Methodological triangulation as a prerequisite for research processes. Authors' own research.

When analysing the obtained results, the vast majority of respondents believe that methodological triangulation is a necessary condition in research processes $(65.84 \%)$. Only a small part of researchers $(10.72 \%)$ feel that there is no such condition. What is more, $23.44 \%$ of respondents indicate lack of awareness or even ignorance as to the scope in question, which may make the selection of one appropriate method problematic. This will undoubtedly disturb the test results. At the outset, the researcher should assume that the selection of several good methods provides more complete information and will allow to get to know the examined phenomenon better, instead of focusing on the selection of one best method.

\subsection{Does the researcher influence the fusion of quantitative and qualitative methods in the research process?}

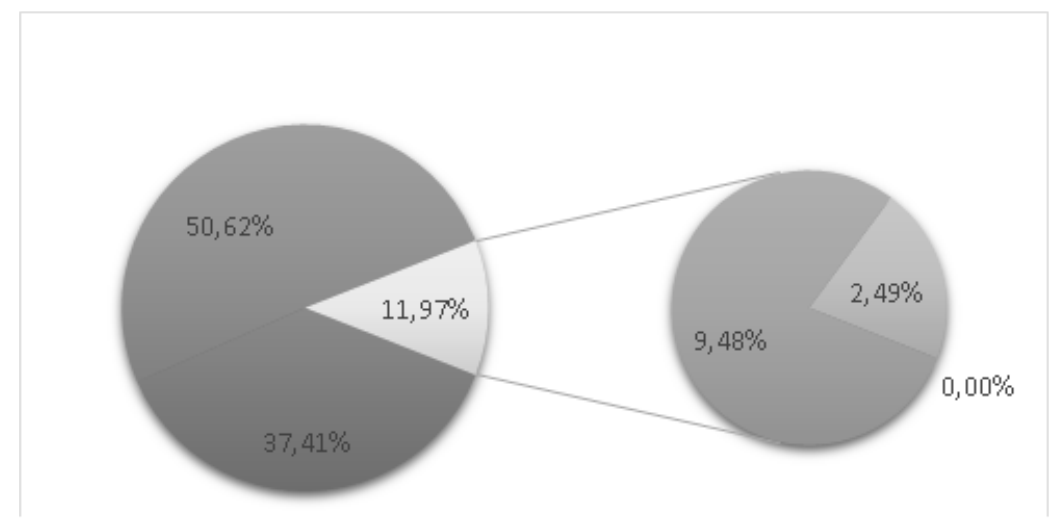

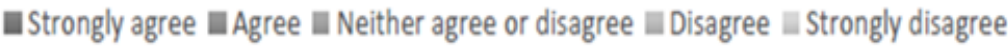

Figure 2. The influence of the researcher on combining quantitative and qualitative methods in the research process. Authors' own research. 
The vast majority of respondents $(88.03 \%)$ believe that the researcher can influence the combining of quantitative and qualitative methods in the research process. Only $2.49 \%$ of respondents believe that they rather do not have such an influence, and $9.48 \%$ do not have any knowledge in the discussed scope. In practice, most positivists do not insist on their epistemological standpoint and resort to qualitative methods where quantitative methods would be inappropriate. Furthermore, most relativists or constructivists do not use quantitative analysis, but they can refer to it. To sum up, a researcher with a propensity for quantitative methods will use the quantitative method as the basic method, and qualitative methods as a supplement and verification. The researcher with a tendency to qualitative methods will do the opposite, because he/she may want to check the obtained result additionally using quantitative methods. For this purpose, detailed research on the selection of research methods and techniques should be carried out, depending on the epistemological position taken.

\subsection{Having developed a research question, is it necessary to analyse selected quantitative and qualitative methods in order to make a preliminary selection?}

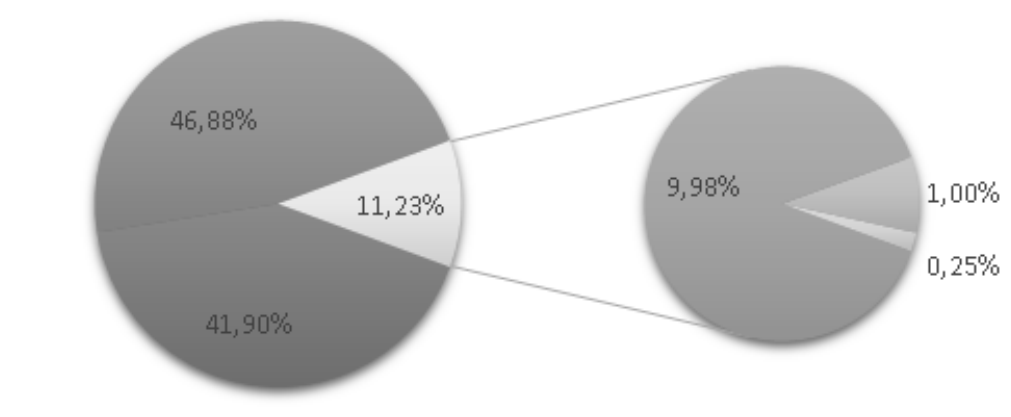

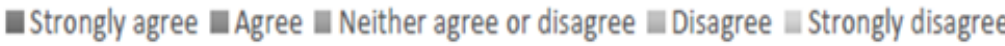

Figure 3. Necessity to analyse selected quantitative and qualitative methods upon the formulation of the research problem. Authors' own research.

While analysing the achieved results, one may undoubtedly state that upon formulation of the research problem, it is necessary to analyse the chosen quantitative and qualitative methods in order to pursue their preliminary selection (88.77\% respondents). One may find arguments to support the above-mentioned thesis in the source literature (Dźwigoł et al., 2019), where it is claimed, more often than not, that in order to diagnose the research problem comprehensibly and thoroughly, it is necessary to apply diverse research methods, providing an exhaustive answer to the posed question. Furthermore, the very development of heterogenous cognitive methods, modelling or organisation management has an impact on the necessity to adopt an open-minded approach, allowing or even encouraging to combine numerous approaches and methods. Practical aspect of the devised methods, procedures or models were verified in order to make the research more reliable. Moreover, before undertaking research studies, it is necessary to analyse the chosen methods against the character of the carried-out research (Thomas, 2017; O’Leary, 2017). 


\subsection{Does methodological triangulation support research processes?}

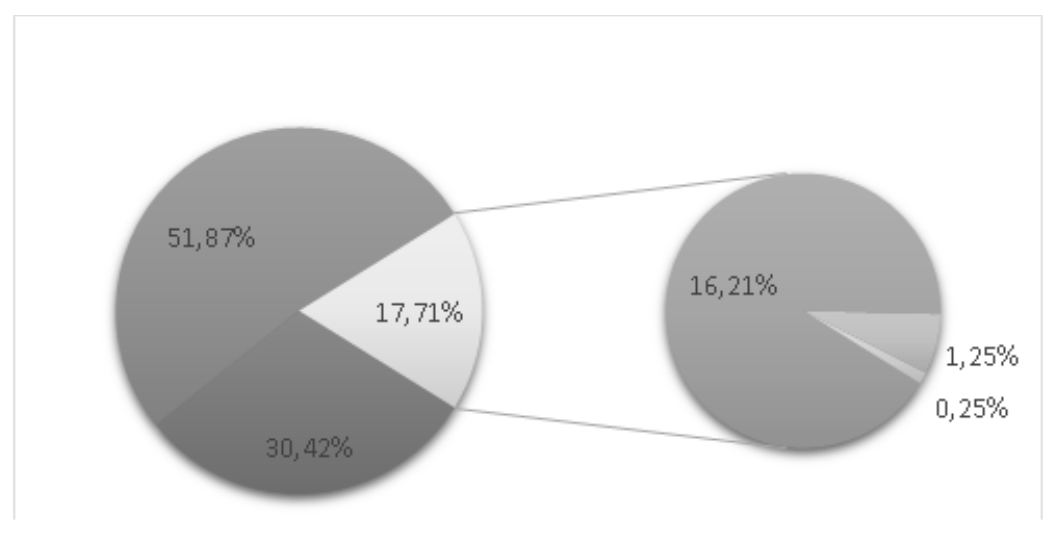

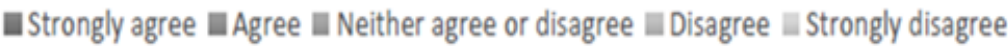

Figure 4. Methodological triangulation as a determinant supporting the research process. Authors' own research.

The achieved results confirm that the methodological triangulation supports the research process $(82.31 \%)$, which was confirmed by an extensive literature study on the research methodology. It was stated in the said literature that the application of numerous differentiated methods in the research process allows to adopt a complex approach to the research problem, while providing it with a broader image.

\subsection{Does combining qualitative and quantitative methods in management-related research processes enhance the quality and reliability of research findings?}

According to the interviewed experts, combining quantitative and qualitative methods in the management-related research processes shall considerably affect the quality of the process itself and reliability of the research findings. Furthermore, the experts state that it is not always easy, in practical research studies, to make a clear distinction between quantitative and qualitative methods, where specific conditions should be met, e.g. an order of applying particular methods or objectivism as to research findings. What is more, K. Pająk (2010, p. 185 $\&$ n.), Professor, expresses the opinion that qualitative research in management science focuses on a more comprehensive analysis of a given phenomenon. The main emphasis is put on understanding the analysed problem, in a better and more precise way, with the use of special research methods. The qualitative research, as opposed to the quantitative one, is not structured to a considerable extent, due to the lack of quantitative approach, as statistical inference is not applied very often. In an ideal methodological situation, if a researcher is willing to study or discover something, verify a set hypothesis or research question, then the quantitative and qualitative research should complement each other.

Functions and usefulness of both kinds of methods and their combination are certainly diverse, among other things due to the research subject and research goals, as well as the phase of the research process. Nonetheless, should the researchers' interest evolve around discovering and/or recognising (combined with interpreting) cause-and-effect relations, or mechanisms in 
which functions and processes are carried out, its underlying factors and further consequences, as well as subsequent formulation of research hypotheses, then the quantitative methods should be obligatorily supported by (additional) qualitative methods.

\section{Summary and research findings}

The aim of the paper was to verify the following hypothesis: 'Methodological triangulation supports research processes in management science'. Statistical inferencing resulting from the research conducted among the scholars in management science clearly indicate that a significant part $(66 \%)$ believes that methodological triangulation is a necessary prerequisite in the research process. Moreover, as many as $82 \%$ of the above respondents claim that triangulation supports the research process.

The obtained results also confirm the wide literature research on research methodology, where it is noted that the use of many different methods in the research process enables a comprehensive approach to the research problem and develops a more comprehensive picture of it. Methodological triangulation is also an answer to the problem of selecting one suitable method, which can undoubtedly interfere with the research results. At the outset, the researcher should assume that the selection of several good methods provides more complete information and will allow for a better understanding of the examined phenomenon, instead of focusing on the selection of one best method.

The above statements are also corroborated by the claims of scientists specialising in management science who participated in the structured (standardized) interview. When answering the question concerning the combination of qualitative and quantitative methods in the research process, the respondents referred directly to the improved reliability and quality of the obtained research results. At the stage of defining a research problem, it is currently difficult to choose one method that allows for a full and thorough diagnosis of the problem. Therefore, it is necessary to use a variety of research methods that provide a comprehensive response to the posed research problem. 


\section{References}

1. Almalki, S. (2016). Integrating Quantitative and Qualitative Data in Mixed Methods Research-Challenges and Benefits. Journal of Education and Learning, 5(3), doi:10.5539/jel.v5n3p288.

2. Apuke, O.D. (2017). Quantitative Research Methods: A Synopsis Approach. Arabian Journal of Business and Management Review, 6(10), DOI: 10.12816/0040336.

3. Boddy, C. (2016). Sample size for qualitative research. Qualitative Market Research, 19(4), 426-432. https://doi.org/10.1108/QMR-06-2016-0053.

4. Bryman, A. (2006) Integrating quantitative and qualitative research: How is it done? Qualitative Research, 6(1), 3-37, https://doi.org/10.1177/1468794106058877.

5. Dźwigoł, H. (2018). Wspótczesne procesy badawcze $w$ naukach o zarządzaniu. Uwarunkowania metodyczne i metodologiczne. Warszawa: PWN.

6. Dzwigol, H., Aleinikova, O., Umanska, Y., Shmygol, N., \& Pushak, Y. (2019). An Entrepreneurship Model for Assessing the Investment Attractiveness of Regions. Journal of Entrepreneurship Education, 22(SI1), 1-7.

7. Dźwigoł, H., Dźwigoł-Barosz, M., Zhyvko, Z., Miśkiewicz, R., Pushak, H. (2019) Evaluation of the energy security as a component of national security of the country. Journal of Security and Sustainability Issues, 8(3), 307-317. http://doi.org/10.9770/ jssi.2019.8.3(2).

8. Ferran-Ferrer, N., Guallar, J., Abadal, E., and Server, A. (2017). Research methods and techniques in Spanish library and information science journals (2012-2014). Information Research, 22(1).

9. Hair, J.F., Page, M., and Brunsveld, N. (2019). Essentials of Business Research Methods. New York: Routledge, https://doi.org/10.4324/9780429203374.

10. Hammarberg, K., Kirkman, M., and de Lacey, S. (2016). Qualitative research methods: when to use them and how to judge them. Human Reproduction, 31(3), 498-501, https://doi.org/10.1093/humrep/dev334.

11. Hessen, R., Bright, L.K., and Zucker A. (2019). Vindicating methodological triangulation. Synthese, 196(8), 3067-3081, https://doi.org/10.1007/s11229-016-1294-7.

12. Jick, T.D. (1979) Mixing Qualitative and Quantitative Methods: Triangulation in Action. Administrative Science Quartely, 24(4), 602-611, DOI: 10.2307/2392366.

13. Joslin, R., and Müller, R. (2016). Identifying interesting project phenomena using philosophical and methodological triangulation. International Journal of Project Management, 34(6), 1043-1056, https://doi.org/10.1016/j.ijproman.2016.05.005.

14. Kostera, M. (2003) Antropologia organizacji. Metodologia badań terenowych. Warszawa: PWN. 
15. Pająk, K. (2010) Rozwój lokalny jako kategoria ekonomiczna. In: A. Grzelak, K. Pająk (Eds.), Nowe trendy w metodologii nauk ekonomicznych (pp. 185-215). Poznań: Wydawnictwo Uniwersytetu Ekonomicznego.

16. Park, J., and Park, M. (2016). Qualitative versus Quantitative Research Methods: Discovery or Justification? Journal of Marketing Thought, 3(1), 1-7.

17. Quinlan, Ch., Babin, B., Carr, J., and Griffin, M. (2019). Business Research Methods. South Western Cengage.

18. Stańczyk, S. (2016) Triangulacja - łączenie metod badawczych i urzetelnienie badań. In: W. Czakon (Ed.), Podstawy metodologii badań w naukach o zarzadzaniu. Warszawa: Oficyna Wolters Kluwer Business.

19. Thomas, G. (2017). How to Do Your Research Project: A Guide for Students. London: Sage. 20. Tonidandel, S., King, E.B., and Cortina, J. (2016). Big Data Methods: Leveraging Modern Data Analytic Techniques to Build Organizational Science. Organizational Research Methods, 21(3), 525-547, DOI: 10.1177/1094428116677299.

21. Vaivio, J., \& Sirén, A. (2010) Insights into method triangulation and "paradigms" in interpretive management accounting research. Management Accounting Research, 21(2), 130-141, https://doi.org/10.1016/j.mar.2010.03.001.

22. Walliman, N. (2017). Research Methods: The Basics. London: Routledge. 